\title{
Integration of ICT, Drama, and Language for Development of Children's Communicative Competence: Case Study in a Primary School
}

\author{
Giedrè STRAKŠIENE் ${ }^{1}$, Dalia BAZIUKAITÉ ${ }^{2}$ \\ ${ }^{1}$ Klaipeda University, Department of Pedagogy \\ ${ }^{2}$ Klaipeda University, Department of Computer Science \\ Herkaus Manto 84, LT-92294 Klaipèda, Lithuania \\ e-mail: giedre.straksiene@ik.ku.lt,dalia.baziukaite@ku.lt
}

Received: October 2008

\begin{abstract}
The paper addresses the issue of unusual ICT tool application in the development of communicative competences during drama classes. It also presents the practical implementation of a case study method with the application of ICT tools. The case method was used for an interesting combination of acquiring communicative competences including drama skills by means of applying modern computer software. The target group was the 3rd form pupils of Klaipeda primary school. The activities planned to cover skills of language, drama and ICT.

The significance of the presented case is based on the following: pupils' communicative skills are improved; learning is based on the integration of inherently different subjects, such as drama, language and ICT; skills of the three subjects are educated in a creative way. ICT can act as a promoter of educational change only if learners and teachers have an access to the new technology and it is intensively used as a tool for learning in various subject domains.
\end{abstract}

Keywords: case study method, ICT, embeded ICT, integrated teaching methods.

\section{Introduction}

The challenge to current educational system for the future is to prepare learners to participate in a knowledge society, in which knowledge is the most critical resource for social and economical development. Educational institutions are required to find appropriate pedagogical methods to cope with these new challenges (Hakkarainen, 2000). In order to develop communicative competence in a primary school, new methods and forms of teaching should always be under consideration. For certain goals, tasks in game format are usually used, known as didactic games, or it can be practical tasks of writing and reading during language lessons. Development of technology and new computer-based game possibilities make an impact on art specialists as well, making them think about possible application of ICT in their subjects. Until now, ICT is rarely used as a tool for drama tasks in Lithuania.

If properly taught and used, information communication technologies (ICT) could play an important role as tools for the general restructuring of learning processes, facil- 
itate development of collaborative skills and increase productivity when working with information. Such skills have an impact even outside of technical subjects areas.

The Case Method is a method of learning that is based on active participation, cooperation, and democratic discussion of a practical situation presented in the form of a fiction story or an actual case. A particular case study of technology application was one of the activities of CaMOT (Case Method of Technology for Practical Use of Training Teachers) project ${ }^{1}$, supported by the European Commissión Socrates Programme, with Klaipeda University as one of the partners.

Social skill (abilities) have significant role in relations with other peoples as with members of a society. That is why it is important to develop communicative competence starting from the youngest age at primary school. Teachers should not neglect the social aspect in language learning, too. Teachers are trying to find new ideas, materials and methods how to develop communicative skills, however, they most often tend to use traditional methods (Šernas, 2006).

The problem is that traditional methods do not provide sufficient opportunities to develop the communicative competence of speaking. Learners train their communicative competence skills, but not to a sufficient degree, as they begin competing and do not try to reach individual and common goals. Communicative competence, and particularly speaking skills, could be best developed through the case study method at primary school.

The educational reform ideas in Lithuania and experience of educators from Western countries stimulate the active use of various training methods in Lithuania. Nowadays teachers have a good opportunity to teach, train learners in nontraditional ways.

The main question is how can the integration of ICT, language and drama help to improve development of communicative competence at primary school? Following the question, the main goal will be to prepare a program of the experiment and verify the program.

With the case study, we intended to show that learning a language is not only a process of learning grammar, but also a social one. Arts and creative activities can be viewed as study subjects in social-educational sciences. Modern program on primary education is oriented to the development of pupils' competences. The content of its development does not eliminate subjects, but helps teacher to better understand that the goal of the educational process is a child with developed personal competences, but not a subject that should be taught by a teacher and learned by a pupil (Educational standards, 2003). New perspectives of linkage between drama, language learning skills, and information communication technologies (ICT) skills were an area of our interest.

The activity took place in a primary school. Two teachers (the form teacher and the drama teacher) were guiding case activities. The pupils involved came from Forms 3 to 4 of the primary school. Primary school in Lithuania consists of 4 forms (from the 1 st to the 4th). The students of the third form are at the verge of adolescence, and their interests are diverse, as they start seeing the world in different ways. Various aspects become important to them, and the teacher's role is to keep them interested and help them to develop in a

\footnotetext{
${ }^{1}$ http : / /www. camot. net.
} 
variety of ways. Social skills are important and are not to be neglected. In the school, which was selected for the case study activity, pupils are taught various subjects, starting from the main subjects, such as mathematics, language, and literature, and ending with art subjects.

The activities planned in the case covered skills from language and literature, drama and ICT. Language and literature skills are mainly listening, writing, and creating dialogs. Drama skills are recognition of emotions and mimic and improvement of speaking quality. ICT skills are typing a text, managing a standard voice recorder, and manipulating other standard computer software.

The case was conditionally divided into five steps. In the first step of the case, children read materials and watched photo-mimic presentation. In the second step, pupils had to solve several types of tasks, e.g., to find a matching description of an emotion, or to find a suitable description for a given emotion or mimic. In the third step, pupil were presented with a recorded video situation in which two people communicated. The film was shown without sound. Pupils then could write dialogs in the next step. The fourth step included dialog creation and their recording with the help of a standard voice recording software and typed texts. The fifth step was devoted to the presentation of created dialogs. Teacher collected all the created dialogs and played them one after another. At the end, the film was played with the original sound, and the results were compared.

The communicative competences depicted in Fig. 1 are trained by the case activities. The significance of the presented case is based on the following:

- Pupils' communicative skills are improved.

- Learning is based on the integration of inherently different subjects, such as drama, language and ICT.

- Skills of the three subjects are educated in a creative way.

The next section gives short description on case study method. Section 3 will explain a notion of communicative competences and the role of basic emotions in developing described competences. Section 4 will present a run of case study at primary school with

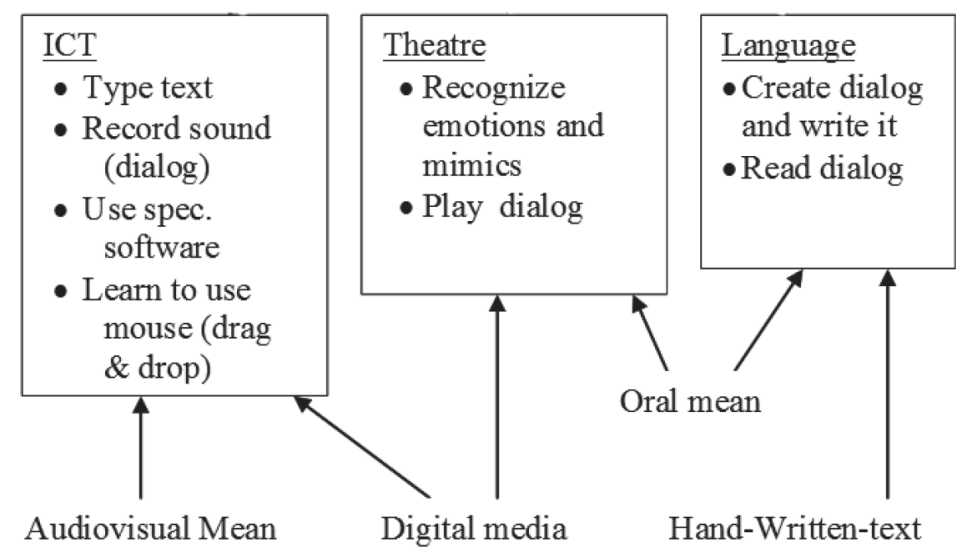

Fig. 1. Trained communicative competences and their relation. 
an application of a tool we created specially for practical implementation of the case activities. Section 5 will analyse pupil achievements during an experimental lesson at school. Finally, we will conclude with summary of results and vision for the future work.

\section{Case Study Method}

The students can learn more effectively, if they are actively involved in the learning process (Bonwell and Eison, 1991; Sivan et al., 2000). The case study approach is one of the ways to implement active learning strategies in schools. There is a number of definitions for a term "case study". E.g., Fry et al. (1999) describes case studies as complex examples which give an insight into the context of a problem as well as illustrate the main point. Fry defines case studies as student-centred activities based on topics that demonstrate theoretical concepts in an applied setting. That definition of a case study covers a variety of different teaching structures they use, ranging from short individual case studies to longer group-based activities. Educational research has shown case studies to be useful pedagogical tools. Grant (1997) outlines the benefits of using case studies as an interactive learning strategy, shifting the emphasis from teacher centred to more studentcentred activities. Case studies have also been linked with increasing student motivation and interest in a subject (Mustoe and Croft, 1999).

From our point of view, case studies are useful, because they:

- allow to demonstrate theoretical concepts in application, thus bridging the gap between theory and practice;

- encourage active learning;

- provide an opportunity to develop key skills, such as communication, working in groups, and problem solving.

The case method is based on a learning principle that states: people learn best when they teach themselves through their own effort. One can gain greater understanding and improve skills in judgement when one works through a problem, but not just passively listens to a lecture. Similarly, there will be greater learning results if someone "uses" a theory in practice.

Case studies can help us in learning to:

- apply theories to real situations;

- solve real problems.

Like real situations, cases center around an array of partially-ordered, ambiguous, seemingly contradictory and reasonably unstructured facts, opinions, inferences and bits of information, data, and incidents out of which some one must provide order by selectively choosing which bits to use and which to ignore. In real life, others will not do this for us. Similarly, in real life situations, it is unlikely that any two people would assemble the data or make inferences identically. Some one will have to work within the limitations inherent in evidence and arrive at internally consistent interpretations. Experiencing the process of learning this way may be frustrating and confusing, but it is also practical and realistic. 


\section{Basic Emotions within Communicative Competences}

Talking about communicative competence and their development, the emphasis is placed on communication and creativity. That is due to the impact of the human communicative action during life: the readiness to communicate, which means an ability to express one's own thoughts, feelings, opinion, and emotions in different situations, to transmit information in a precise way, to have an ability to create various types of texts, to be polite and follow cultural standards. Communicative competence is a complex psychological, pedagogical, social and physiological process that allows a person to interact, to send and receive information (in all oral, written, gesture and mime forms) and to become a full member of the knowledge society. Communicative competence:

- is the ability to get what you are seeking from others in a manner that maintains the relationship on terms that are acceptable to all parties (Adler and Towne, 2003);

- does not mean behaving the some way in all settings and with all people; competence varies from one situation to another;

- is an aggregate of individual abilities, knowledge and experience that conditions self-confidence and correct orientation when communicating with each other (Psichologijos žodynas, 1993).

In addition to assessing the management of the interactions, a holistic approach according to the basic principles of tandem learning - will seek to establish a balance between assessment of linguistic content, discourse abilities and sociocultural competence. These paradigms are based on the four-pronged model of communicative competence developed by Canale and Swain (1980) and subsequently refined by Canale (1983). A further examination of the data can be undertaken with the aid of conversation analysis as initially developed by Sacks (1992) and Schegloff (1980). Such an analysis can seek to ascertain whether the basic rules of turn-taking are respected and focus on some specific discourse areas such as topic introduction and management, issues of communicative breakdown and repair strategic competence (Schwienhorst, 2002) and communicative adaptability (as studied by Accommodation Theory (Chen and Cegala, 1994)). These works can be referenced at a given link $^{2}$ as well. Real Decreto 1006/1991 of 14 th of June establishes the teaching requirements for Primary Education nation-wide. In it, communicative competence comprises five subcompetences: grammar competence, sociolinguistic competence, sociocultural competence, discourse competence, strategic competence.

For Hymes (1972) the Communicative Competence has four aspects: systematic potential, appropriacy, occurrence, feasibility. These categories have been adapted for teaching purposes.

The majority of students understand emotions as feelings that come up in different situations. Another part of students explain them as being "what the body tells us". To describe feelings is a rather difficult task to students. Social scientists generally agree that a phenomenon known as "feeling" consists of several components. It is impossible to talk

\footnotetext{
${ }^{2}$ http: //www. llas.ac.uk/resources/goodpractice. aspx? resourceid=411.
} 
about communication without acknowledging the importance of emotions. The role of emotions in human affairs is apparent to social scientists and laymen alike. According to psychologists Sternberg (1985) and Goleman (1995) there is such a phenomenon as "emotional intelligence".

Goleman (1995) makes the claim that intellectual ability is more than a way to measure one's talents and that success in the world greatly depends on the ability to understand and manage one's own emotions, as well as and to empathize. E.g., every thought, gesture, muscle, tension, everything is significant and meaningful, and related to the present. It is possible to know and understand oneself on all these levels, and the more one knows the more he/she is free to determine their own life.

The types of emotion are: primary and mixed emotions, and mild and intensive emotions. Famous psychologist Pluchik (1980) has identified eight primary emotions (joy, acceptance, fear, surprise, sadness, disgust, anger, anticipation) and those primary emotions can combine to a mixed form (optimism, love, submission, awe, disappointment, remorse, contempt, aggressiveness). In real situations, we would probably feel mixed emotions. Emotions can be sorted according an intensity state.

During the experiment, pupils had to recognize emotions from photos taken from their own school life. This is a way to provide information to students on how emotions are expressed in speech. The task was to create an audio clip in accordance with emotional situations presented in the photos (see next section for details).

\section{Run of Case Study at Primary School}

It has been shown (Passey et al., 2003) that ICT has a positive inpact on pupils' motivation and it engages pupils more into the learning as they get elder. Usage of ICT helps for students to keep focus on learning goals indicating their concentration to the learning. Having in mind the positive impact of ICT on pupils' motivation, we have created a simple html-based tool, which we have used during the experiment at the school. It consists of a collection of materials (photos, videos, text, guizes) that pupil learn, or at least look through, trying to understand different types of emotions, mimics and their importance in people communication. This collection of materials builds the basis for the learning processes such as engagement and research.

According to Passey et al. (2003) we consider the following learning processes: 1) engagement, 2) research, 3) writing and 4) presentation. The created tool covers only the processes of engagement and research, where

- engagement process is implemented through viewing texts and simple graphics, and audio visual means;

- research process can be accomplished by searching and accessing the materials.

The rest two learning processes

- writing,

- presentation

are realised through the standard computer software such as text editor, audio recorder and presentational software. 
A tool, as it was used during the experimental lesson, is available for viewing online ${ }^{3}$ in Lithuanian language. It contains all five stages that train different types of skills (Fig. 1) included in the presented case study. The stages of the case we have qualified as follows:

1. Discover. Texts and simple graphics or even video material are presented.

2. Apply. Solve several types of tasks.

3. Observe. Pupils are presented with recorded video situation in which two people communicate.

4. Create. Write dialog, type it, record it.

5. Present. Present created dialog.

In the first stage of the case, two types of emotion description were presented to pupils. First, in the written form, they were presented with the structure of three rows for each emotion - the title, a photo expressing the emotion, and a short story describing possible feelings and thoughts captured in the photo (Fig. 3). Then, they watched slides with recorded explanation of the emotions expressed in the previously presented photos. The second stage was equiped with quizes that are created with Hot Potatoes tool ${ }^{4}$. During this step pupils had an opportunity to test their previous experience and possibly apply the newly acquired knowledge from the first stage of the case study.

The third stage was supported with example dialogs. The dialogs were cre-ated in accordance with the situation expressed in the photo, coming together with a particular dialog. There were three dialogs. The activity of that stage helped pupils to prepare for the next stage, in which they created in their own way.

During the fourth stage, children created a text in accordance with a selected picture, wrote it down on the paper by hand, and afterwards typed the text using the text processor (Figs. 2, 4). For that activity, the tool included photos and video with different situations. After typing the dialogs in a text processor, pupil used standard audio recorders that came together with an operating system, and recorded their dialogs.

The fifth stage was devoted to the presentation of the dialogs created (Fig. 5) in accordance with the given situations expressed in the photos or video materials.

All the results of the practical implementation of the case study were collected and presented in the CaMOT project website ${ }^{5}$ under the case entitled "Learning to recognise emotions. A case in primary school".

\section{Pupil Achievements}

Small research was carried out as well. Table 1 summarizes the results of quiz answers. The columns of the table represent a number of pupils who answered the quiz questions with $100,66,33$ and 0 percentage of quality. Figs. 6-11 show some dialogs in their written and typed form. As can be seen in the pictures representing handwritten and typed

\footnotetext{
${ }^{3}$ http://ik.ku.1t/ dalia/camot

${ }^{4}$ http: //hotpot.uvic.ca.

${ }^{5}$ http: / / www . camot. net.
} 


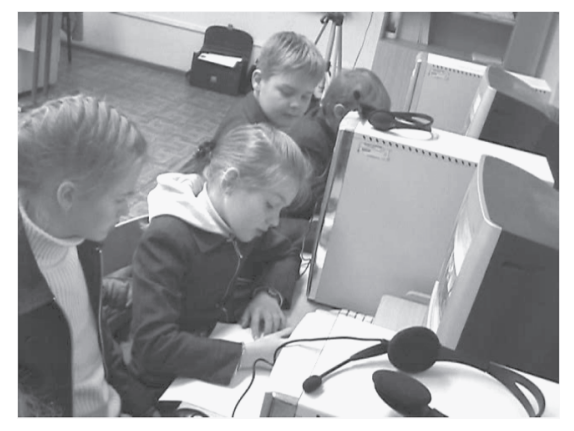

Fig. 2. Using specially prepared materials.

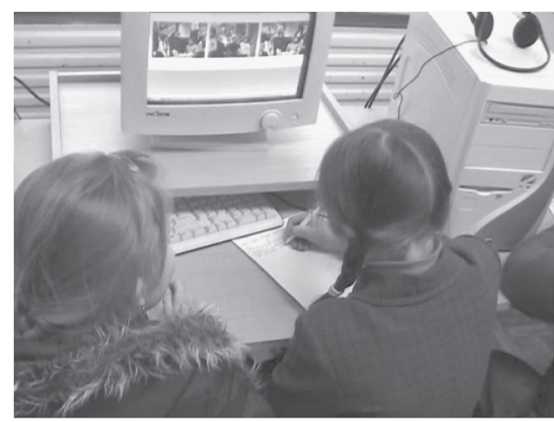

Fig. 4. Creation of dialog.

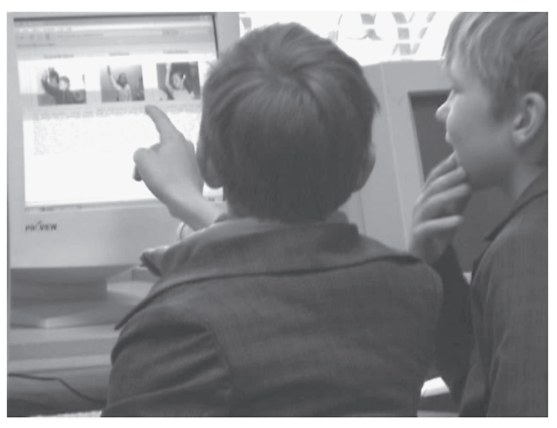

Fig. 3. Working in pairs.

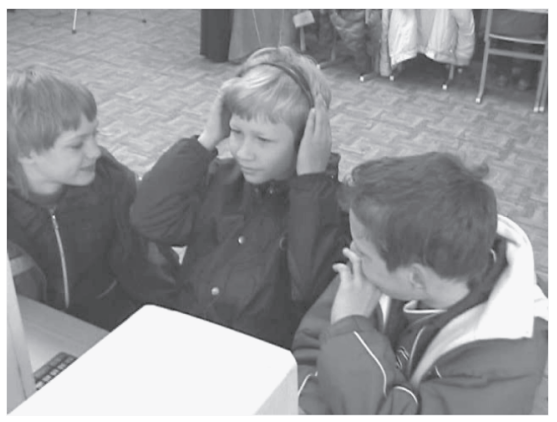

Fig. 5. Listening to the self recorded track.

examples of dialogs, grammar mistakes made in the written forms of a dialog usually remain in the typed version of it. An interesting moment is that pupils make new ones while typing dialogs into a text processor. That might be explained as a lack of concentration while doing such a type of tasks at this age. Also, an impact of modern mobile technologies should be under consideration, because it is not a secret that people prefer to write SMSs without using special characters of Lithuanian language.

As it was explained in the introductory section of the paper, pupils from one of Klaipeda secondary schools took part in the experiment. The experiment was carried out in May, 2007. 26 students from the 3rd form of primary school took part in practical activities.

In section 4 , every stage of the case study was explained. Some conclusion can be made after summarizing the results of the answers to the quiz questions, in which they had to recognize emotions (from the stance, mimics, ges-tures, signs) that were shown in the photos. Afterwards, the pupils tried to identify the emotions in the photos. The summary of the results of Table 1 is presented in Fig. 12; in accordance with it:

- always identifies correctly $(100 \%)-32 \%$,

- often identifies correctly $(66 \%)-35 \%$, 


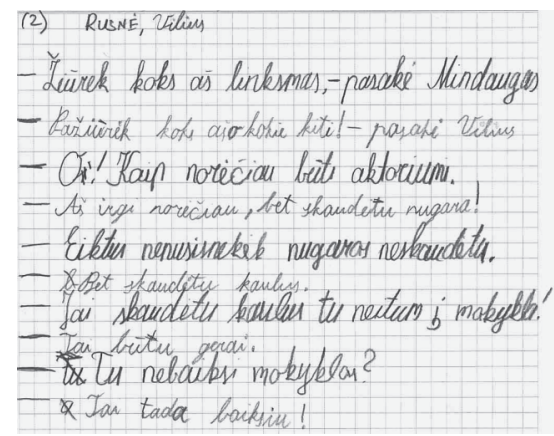

Fig. 6.
(2) RUSNĖ,VILIUS

-Žiūrèk koks aš linksmas,-pasakè Mindaugas. -Pažiūrèk koks aš o kokie kiti-pasakè Vilius.

-O!Kaip noréčiau būti aktoriumi.

-Aš irgi norečciau,bet skaudètu nugara.

-Eiktus nenusišnékẻk nugaros neskaudètu.

-Bet skaudètu kaulus.

-Jai skadètu kaulus tu neitum ị mokykla!

-Tai būtu gerai.

-Tu nebaiksi mokyklos?

-Tai tada baiksiu!

Fig. 7.

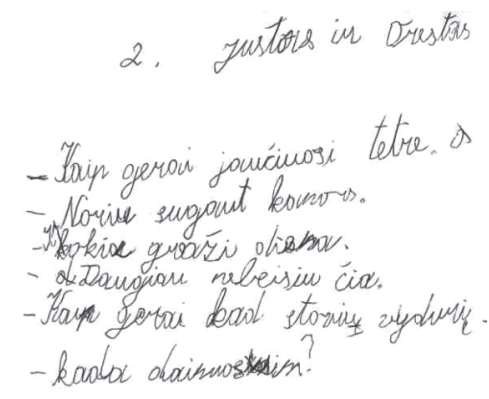

Fig. 8 .

\section{Justas ir Orestas}

-Kaip gerai jaučiuosi teatre. -Noriu sugautkanors.

-Kokia graži diena.

-Daugiau nebeisiu čia.

-Kaip gerai kad, stoviu čia. -Kada dainuosim.

Fig. 9.

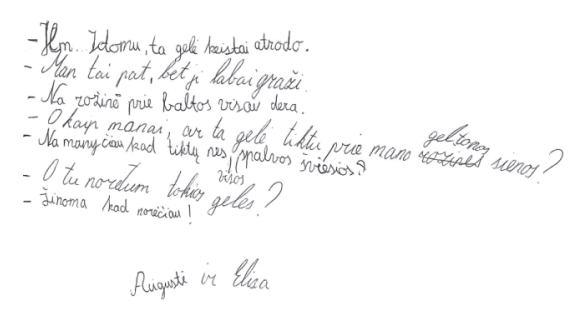

Fig. 10.
Hum... idomu ta gèlè keistai atrodo.

Man tai pat, bet ji labai graži.

O kaip manai, ar ta gèlè tiktu prie mano geltonos sienos?

Na manyčiau kad tiktų nes visos spalvos šviesios.

O tu norétum tokios gèlés?

Žinoma kad noréčiau!

Augustè ir Eliza

Fig. 11.

- sometimes identifies correctly $(33 \%)-31 \%$,

- never identifies correctly $(0 \%)-2 \%$.

In summation, every case of a dialog, a subtext (what it is hidden under the pronounced text) comes out. Participants of a dialog can hear the intonation and feel the emotive state of a person, can decide on their temperament and other things that can only be seen in communication. Next to the verbal language, a language of a different dimension exists, and it is called non-verbal language. Often it provides more information than the first one and influences the verbal language. Learning to talk by using the opportunities of non-verbal language is important from primary school. The combination of verbal 
Table 1

Distribution of pupil answers to four given quizes

\begin{tabular}{ccccc}
\hline Number of answers & $100 \%$ & $66 \%$ & $33 \%$ & $0 \%$ \\
\hline 1 task & 20 & 2 & 4 & 0 \\
\hline 2 task & 7 & 9 & 8 & 2 \\
\hline 3 task & 4 & 15 & 7 & 0 \\
\hline 4 task & 2 & 11 & 13 & 0 \\
\hline
\end{tabular}

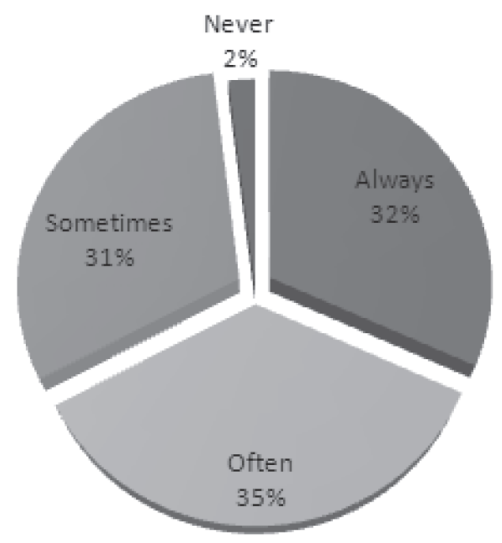

Fig. 12. Answer distribution: $67 \%$ of target group was able to identify emotion right.

and non-verbal expression makes a message clear, suggestive, meaningful, original, etc. An important moment is how we are able to manage the content of our language, formulate ideas and express them in a clear way, how we manage our mimic and gesture and how we make our message more suggestive. As it turned out, pupils in the third form could recognize basic emotions rather well. Role-playing games were very useful and contributed to the pupils' getting engrossed in the text and their understanding of its content and emotive background. An interesting task for pupils is the creation of a sound track.

\section{Final Remarks}

The case demonstrated a way how language (written and spoken), drama (moving, mimics, and emotions), and ICT (typing text, managing voice recorder, manipulating satndard computer software) can be used in an integrated way for teaching and acquiring communicative competences. Such a com-bination of tools allows to reach an infinite capacity to express and understand the meaning of different types of communicative phenomena. 
The main focus of the lesson was on the pupils' ability to improve dialogs on the basis of different emotions they identified, given the fact that all the activities were carried out by using modern ICT tools and software.

Traditional approaches treat a language as a free standing package of knowledge, used to analyse and observe it. Many of us have learnt language that way. Learning a language is a very abstract process, and it is known that the traditional approach to learning it does not appeal to everyone. The best results of learning a language are seen when learning becomes a part of our life experience.

One of the most common uses of language for the expressive or emotional purpose is a means of getting rid of our nervous energy, when we are under stress, or are happy and joyful, angry, afraid, etc. Traditional methods of teaching do not give enough opportunities to develop oral communicative competence.

Combined tools incorporating advances of ICT bring new possibilities to methods used for training communicative competences and find their place even in teaching arts and are successfully applied as it was shown in this particular case.

The particular case study can be extended to a broader activity by attracting subject teachers and developing special software tool and teaching methodology.

\section{Acknowledgments}

Most of this work was done as activities of CaMOT (Case Method of Technology for Practical use of Training Teachers) project ${ }^{6}$, supported by the European Comisión Socrates Programme, Comenius Action 2.1. Training of School Education Staff 226712CP-1-2005-ES-COMENIUS-C21 under coordination of the University of Cadiz, Spain.

We thank a community of Klaipeda Vydūnas Secondary School for the ability to arrange case study of technology and for their kind participation in the activities.

\section{References}

Adler, R.B., Towne, N. (2003). Looking Out/Looking In. Wadsworth.

Bennett, M. (1997). How not to be a fluent fool: Understanding the cultural dimensions of language. In: Fantini, A.E. (Ed.), New Ways in Teaching Culture. TESOL, Alexandria.

Bendrosios programos ir išsilavinimo standartai (2003). Priešmokyklinis, pradinis ir pagrindinis ugdymas, Vilnius (in Lithuanian).

Bonwell, C.C., Eison, J.A. (1991). Active Learning: Creating Excitement in the Classroom. ASHE-ERIC Higher Education Report No. 1. School of Education and Human Development, The George Washington University, Washington, DC.

Buttjes, D., Byram, M. (1991). Mediating Languages and Cultures: Towards an Intercultural Theory of Foreign Language Education. Multilingual Matters, Clevedon.

Canale, M., Swain, M. (1980). Theoretical bases of communicative approaches to second language teaching and testing. Applied Linguistics, 1(10), 1-47.

Canale, M. (1983). From communicative competence to communicative language pedagogy. In: Richards, J.C., Schmidt, R. (Eds.), Language and Communication. Longman, London, 2-27.

\footnotetext{
${ }^{6}$ http: //www. camot. net.
} 
Chen, L., Cegala, D.J. (1994). Topic management, shared knowledge and accommodation: A study of communication adaptability. Research on Language and Social Interaction, 27(4), 389-417.

Grant, R. (1997). A claim for the case method in the teaching of geography. Journal of Geography in Higher Education, 21(2).

Fry, H., Ketteridge, S., Marshall, S. (1999). A Handbook for Teaching and Learning in Higher Education. Kogan Page, Glasgow.

Goleman, D. (1995). Emotional Intelligence: Why It Can Matter More Than I.Q. Bantam, New York.

Hakkarainen, K. (2000). Students' skills and practice of using ICT: Results of a nattional assesment in Finland. Computers and Education, 34, 103-117.

Hymes, D. (1972). Models of the interaction of language and social life'. In: Gumperz, G., Hymes, D. (Eds.), Directions in Sociolinguistics: The Ethnography of Communication. Holt, Rinehart and Winston, New York.

Little, D. (2003). Tandem language learning and learning autonomy. In: Lewis, T., Walker, L. (Eds.), Autonomous Language Learning in Tandem. Academy Electronic Publications, Sheffield.

Mustoe, L.R., Croft, A.C. (1999). Motivating engineering students by using modern case studies. European Journal of Engineering Education, 15(6).

Passey, D., Rogers, C., Machell, J., McHugh, G., Allaway, D. (2003). The motivational effect of ICT on pupils. Department of Educational Research Lancaster University, Emerging Findings, December 2003.

Penman, C. (2005). Towards a holistic evaluation of communicative ability in tandem interactions. In: Penman, C. (Ed.), Holistic Approaches to Language Learning. Peter Lang, Frankfurt, 187-199.

Pluchik, R. (1980). A language for the emotions. Psychology Today.

Psichologijos žodynas (1993). Mokslo ir enciklopedijų leidykla, Vilnius.

Roberts, C. (2001). Language Learners as Ethnographers. Multilingual Matters, Clevedon.

Sacks, H. (1992). Lectures on Conversation. Blackwell Publishers Ltd., Oxford.

Schegloff, E. (1980). Preliminaries to Preliminaries: Can I ask you a question? Sociological Inquiry, 50, 104 152.

Schwienhorst, K. (2002). Evaluating tandem language learning in the MOO: Discourse repair strategies in a bilingual internet project. Computer-Assisted Language Learning, 15, 135-145.

Sternberg, R.J., Beyond, I.Q. (1985). Cambridge University Press, New York.

Sivan, A., Wong Leung, R., Woon, C., Kember, D. (2000). An implementation of active learning and its effect on the quality of student learning. Innovations in Education and Training International, 37(4).

Šernas, V. (2006). Komunikacinès kompetencijos, jų ugdymo(-si) kai kurios strateginės ir taktinės problemos. Santalka. Filologija. Edukologija, 14(4). 
G. Strakšienè is a graduate of Klaipeda University, Faculty of Liberal Arts. She recieved her master degree in arts in 2002. Now she is a doctoral student in a Faculty of Pedagogy at Klaipeda University. Her research interests are connected to development of communicative competence, integrated learning of subjects including the role of communicative competences in them, various learning methods that can help or could be applied in developing communicative competence.

D. Baziukaitè recieved her doctoral degree in informatics from Vytautas Magnus University and Institute of Mathematics and Informatics in 2007. The doctoral dissertation was devoted to learner oriented methods to enhance capabilities of virtual learning environment. One of her research aspects is focused on adaptivity, intelligence, and decision making processes in virtual learning environments. The topic of ICT application for practical teaching is also of interest. She is a member of the National Association of Distance Education and Lithuanian Society of Mathematicians. 


\title{
IKT, teatro ir kalbos integracija ugdant vaiku komunikacine kompetenciją: atvejo studija pradinèje mokykloje
}

\author{
Giedre STRAKŠIENĖ, Dalia BAZIUKAITĖ
}

Straipsnyje pristatomas praktinis atvejo studijos metodo taikymas, panaudojant IKT įrankius. Šis metodas buvo pritaikytas komunikacinès kompetencijos ugdymui, integruojant teatro, kalbos dalykus ir šiuolaikines kompiuterines technologijas. Atvejo studijos tiksline grupe pasirinkta miesto pradinès mokyklos trečiokai. Suplanuotos veiklos grindžiamos šiais ugdymo proceso aspektais: sudominimu, tyrinejjimu, rašymu ir pristatymu. Kalbos igūdžiu lavinimą sudarè klausymosi, kalbejjimo, rašymo ir dialogu kūrimo veiklos, teatriniu igūdžiu - emociju ir mimiku atpažinimo ir igarsinimo veiklos, IKT igūdžiu - teksto rinkimo kompiuteriu, pelès valdymo, standartinio garso ịrašymo ịrenginio ir programinès įrangos valdymo veiklos.

Pristatyta atvejo studija pagrindžia galimybę ugdyti mokinių komunikacinę kompetenciją, integruojant skirtingus dalykus: teatrą, kalbą ir IKT. Taip pat pastebèta, kad tarpdalykinè integracija didina pradinukų motyvaciją siekiant mokymosi tikslų, aktyvina jų kūrybiškumą. 